\title{
Prediction and Validation of the Austenite Phase Fraction upon Intercritical Annealing of Medium Mn Steels
}

\author{
HUSSEIN FARAHANI, WEI XU, and SYBRAND VAN DER ZWAAG
}

\begin{abstract}
In this research, the effects of $\mathrm{Mn}$ and $\mathrm{Si}$ concentration and that of the isothermal intercritical holding temperature on the austenite-to-ferrite $(\gamma \rightarrow \alpha)$ and the martensite-to-austenite $\left(\alpha^{\prime} \rightarrow \gamma\right)$ phase transformations are studied for a series of Fe-C-Mn-Si steels with up to 7 wt pct Mn. The model is based on the local equilibrium (LE) concept. The model predictions are compared to experimental observations. It is found that the austenite volume fraction at the end of intercritical annealing depends significantly on the initial microstructure. For Mn concentrations between 3 and $7 \mathrm{wt}$ pct, the LE model is qualitatively correct. However, at higher Mn levels the discrepancy between the predicted austenite fractions and the experimental values increases, in particular for the $\alpha^{\prime} \rightarrow \gamma$ transformation. Intragrain nucleation is held responsible for the higher austenite fractions observed experimentally. Silicon is found have a much smaller effect on the kinetics of the intercritical annealing than $\mathrm{Mn}$.
\end{abstract}

DOI: $10.1007 / \mathrm{s} 11661-015-3081-3$

(C) The Author(s) 2015. This article is published with open access at Springerlink.com

\section{INTRODUCTION}

The intercritical annealing treatment involves heating or cooling to and holding at a temperature between the $\mathrm{Ae}_{1}$ and the $\mathrm{Ae}_{3}$ temperature to obtain partial austenitization. The treatment is part of almost any process routes to create multiphase steels. The kinetics of the transformation from austenite to ferrite and vice versa during the intercritical annealing determines the austenite/ferrite fractions and eventually the mechanical properties. Hence the topic has been the subject of continued scientific interest as well as a key factor in the industrialization of multiphase steels. ${ }^{[1-8]}$ It is, therefore, important to develop models for the kinetics and the final phase fractions during intercritical annealing. The models should be capable to handle different initial microstructures corresponding to different process routes and to capture the effects of key alloying elements such as $\mathrm{C}, \mathrm{Si}$, and $\mathrm{Mn} .^{[9,10]}$

It has been shown that in steels with a low concentration of $\mathrm{Mn}$, the $\mathrm{Mn}$ enrichment at the moving austeniteferrite interface is of crucial importance in determining the transformation kinetics. ${ }^{[1-17]}$ Three main concepts have been formulated to describe the transformation between austenite and ferrite in the two-phase region: (i) Full equilibrium $(F E)^{[18]}$ in which all alloying elements redistribute till equilibrium is reached everywhere in system. In the case of FE, the fraction of ferrite or austenite in the intercritical region is fixed at a given temperature, irrespective of the starting microstructure.

HUSSEIN FARAHANI, Ph.D. Student, WEI XU, Assistant Professor, and SYBRAND VAN DER ZWAAG, Professor, are with the Novel Aerospace Materials Group, Faculty of Aerospace Engineering, Delft University of Technology, Kluyverweg 1, 2629

HS, Delft, The Netherlands. Contact e-mail:w.xu@tudelft.nl

Manuscript Submitted November 13, 2014.

Article published online August 11, 2015 (ii) para equilibrium $(P E)^{[19,20]}$ in which it is assumed that the phase transformation can proceed without any redistribution of the substitutional alloying element $\mathrm{M}$ $(\mathrm{M}=\mathrm{Mn}, \mathrm{Si}, \mathrm{Mo}$, etc. $)$ and only the Carbon redistributes such that the chemical potential of carbon across any austenite-ferrite interface is constant. At a certain temperature, there is only one PE tie-line, which means that the PE fraction of ferrite or austenite is also fixed at that specific temperature. (iii) Local equilibrium $(L E):^{[21-}$ ${ }^{25]}$ In the LE model, the interface is assumed to migrate under full LE with partitioning of both $\mathrm{C}$ and $\mathrm{M}$. Due to the large difference in the diffusivities of $\mathrm{C}$ and $\mathrm{M}$, there are two different transformation modes: (a) $L E$ with negligible partitioning (NPLE) mode. In this mode, the concentration of $\mathbf{M}$ in ferrite is the same as that in austenite, but there is a $\mathrm{M}$ spike in front of the migrating interface as a result of the assumed LE condition. The transformation rate is effectively controlled by carbon diffusion and is relatively fast; and (b) LE with partitioning (PLE) mode, in which the carbon gradient in austenite is negligible, while that of $\mathrm{M}$ is large. In this mode, the transformation rate is governed by the rate of $\mathrm{M}$ partitioning, and is extremely sluggish. Depending on the composition of a material, the transformation could start in NPLE mode, and then proceed in the PLE mode. In practice, the point at which the transformation mode switches from NPLE to PLE is regarded as the termination of the transformation. ${ }^{[13-15,26-32]}$ For modest annealing times, the final phase fractions obtained after annealing correspond to the phase fraction achieved in PLE mode. ${ }^{[16,33-35]}$ A similar halting criterion has been formulated in a recent model for a grain growth model involving boundary loading by impurities. ${ }^{[36]}$

Medium and high Mn steels have drawn much attention in recent years in the development of the $3 \mathrm{rd}$ generation advanced high strength steels, combining 
excellent mechanical properties and reasonable material and production costs. ${ }^{28,33,37,38]}$ These steels are generally subjected to intercritical annealing so as to redistribute the $\mathrm{Mn}$ and to tailor the amount, morphology, and stability of the retained austenite after the final cooling. ${ }^{[39-43]}$ For higher Mn concentrations, the transition point from NPLE to PLE during the intercritical annealing, starting from different initial microstructures may differ significantly. Hence the transition conditions are crucial in determining the final microstructure (and the mechanical behavior) in the medium Mn steels. ${ }^{[38,42-46]}$

In a previous study ${ }^{[16]}$ for low Mn steels (Mn levels up to $1.5 \mathrm{wt}$ pct), it was shown that the LE model provides the more accurate predictions of austenite fractions $\left(f_{\gamma}\right)$ after the intercritical heat treatment starting from different initial microstructures, while $\mathrm{FE}$ and $\mathrm{PE}$ models failed to deliver satisfactory estimates. In the current study, the LE model is employed to study the effects of $\mathrm{Mn}$ and $\mathrm{Si}$ additions on the NPLE to PLE transition during the intercritical annealing, for both the austenite-to-ferrite $(\gamma \rightarrow \alpha)$ and the martensite-toaustenite $\left(\alpha^{\prime} \rightarrow \gamma\right)$ transformations, for steels with up to $7 \mathrm{wt}$ pct $\mathrm{Mn}$. The model predictions are compared to experimental metallographic data on samples subjected to well-defined heat treatments.

\section{MODELING AND EXPERIMENTAL PROCEDURES}

The LE and FE models were applied to simulate the $\gamma \rightarrow \alpha$ and the $\alpha^{\prime} \rightarrow \gamma$ transformations in a series of four Fe-C-Mn-Si alloys with compositions listed in Table I, at different intercritical annealing temperatures of $933 \mathrm{~K}, 953 \mathrm{~K}$, and $973 \mathrm{~K}\left(660^{\circ} \mathrm{C}, 680^{\circ} \mathrm{C}\right.$, and $\left.700{ }^{\circ} \mathrm{C}\right)$. While earlier studies in the literature $[13,14,16,27,31,47,48]$ focused on Mn levels up to 3 pct, in this study $\mathrm{Mn}$ levels up to 7 pct are examined both computationally and experimentally. The corresponding Ael and Ae3 temperatures were calculated by Thermo-Calc coupled to the TCFe 7 database. The values calculated for each steel are also listed in Table I. The transformation kinetics simulations were performed using the DICTRA software linked to the TCFE7 and MOB2 databases. Unless stated otherwise, a 1D geometry representing an austenite grain size of $50 \mu \mathrm{m}$ was used in the simulations. To test the effect of cell size on the transformation behavior, the simulations were also executed using different cell sizes. The $\alpha^{\prime} \rightarrow \gamma$ transformation is also modeled assuming the same highly simplified planar geometry for the interface between the martensite and the austenite. In Figure 1, sketches of the initial simulation setups (an austenitic starting state or a martensitic starting state respectively) for the two transformation scenario are shown. The martensite can be modeled by the ferrite phase in DICTRA by imposing the appropriate concentrations and (ferritic) diffusion coefficients. The simulation studies focused only on intercritical annealing conditions. For all simulations, the transformation time was fixed at $10^{4}$ seconds.

Real metallurgical experiments were also preformed to validate the model predictions. In the experiments, the specimens were subjected to heat treatment schemes as illustrated in Figure 2. For the martensite-to-austenite transformation, the specimen was isothermally held at $1173 \mathrm{~K}\left(900{ }^{\circ} \mathrm{C}\right)$ for 900 seconds, followed by water quench with cooling rate of $\sim 75 \mathrm{~K} / \mathrm{s}$, to obtain a full martensitic structure, and subsequently heated to the

Table I. Nominal Composition of Studied Alloys with Calculated A1 and A3 Temperatures by Thermo-Calc

\begin{tabular}{|c|c|c|c|c|c|c|}
\hline \multirow[b]{2}{*}{ Index } & \multicolumn{4}{|c|}{ Nominal Composition in wt pet } & \multicolumn{2}{|c|}{ Calculated Temperatures by Thermo-Calc } \\
\hline & $\mathrm{C}$ & $\mathrm{Mn}$ & $\mathrm{Si}$ & $\mathrm{Fe}$ & A1 & A3 \\
\hline $\mathrm{A}$ & 0.1 & 3.0 & 0 & bal. & $878 \mathrm{~K}\left(605^{\circ} \mathrm{C}\right)$ & $1050 \mathrm{~K}\left(777^{\circ} \mathrm{C}\right)$ \\
\hline $\mathrm{B}$ & 0.2 & 5.0 & 0 & bal. & $818 \mathrm{~K}\left(545^{\circ} \mathrm{C}\right)$ & $991 \mathrm{~K}\left(718^{\circ} \mathrm{C}\right)$ \\
\hline $\mathrm{C}$ & 0.2 & 5.0 & 1.6 & bal. & $823 \mathrm{~K}\left(550^{\circ} \mathrm{C}\right)$ & $1015 \mathrm{~K}\left(742^{\circ} \mathrm{C}\right)$ \\
\hline $\mathrm{D}$ & 0.2 & 7.0 & 1.6 & bal. & $673 \mathrm{~K}\left(400^{\circ} \mathrm{C}\right)$ & $968 \mathrm{~K}\left(695^{\circ} \mathrm{C}\right)$ \\
\hline
\end{tabular}

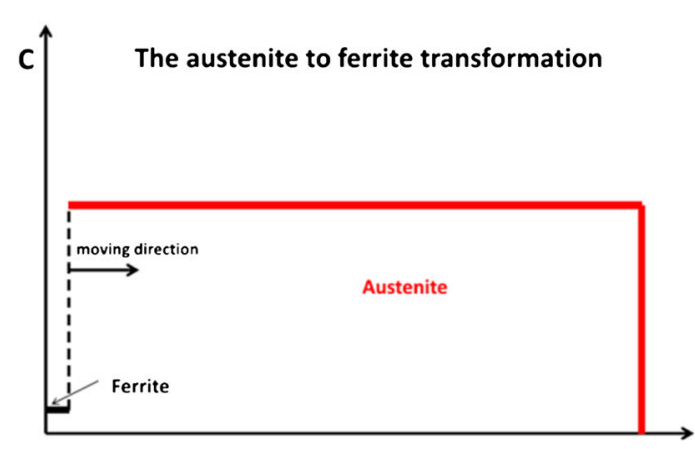

(a)

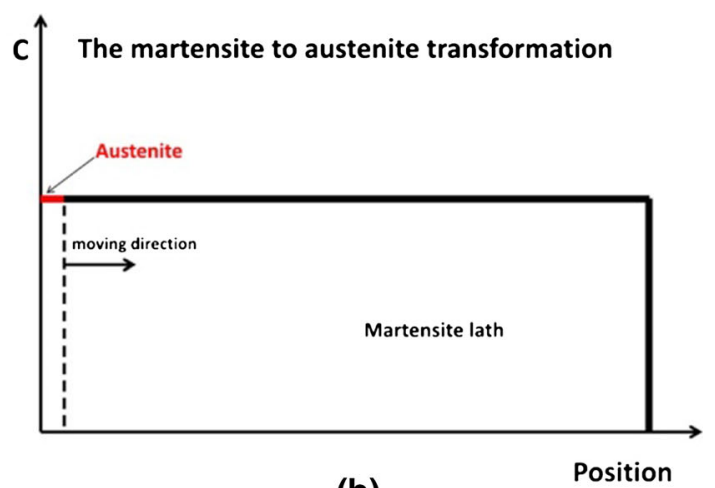

(b)

Fig. 1-Sketch of simulation setup for (a) the austenite-to-ferrite transformation, and $(b)$ the martensite-to-austenite transformation. 
intercritical regime at a heating rate of $\sim 15 \mathrm{~K} / \mathrm{s}$ and kept at the intended temperature for 7200 seconds. For the austenite-to-ferrite transformation, the specimen was austenitized at $1173 \mathrm{~K}\left(900{ }^{\circ} \mathrm{C}\right)$ for 900 seconds and cooled in the furnace with a cooling rate of $\sim 0.5 \mathrm{~K} / \mathrm{s}$ then isothermally kept in the two-phase region for 7200 seconds. Both heat treatment routes were terminated with water quenching at the end of the intercritical annealing. The phase fractions were obtained by quantitative metallography based on optical micrographs after Nital etching.

\section{RESULTS}

In Figure 3, the austenite fractions as a function of time as predicted by LE model during the isothermal holding at $933 \mathrm{~K}\left(660{ }^{\circ} \mathrm{C}\right)$, for either the $\gamma \rightarrow \alpha(3 \mathrm{a})$ and the $\alpha^{\prime} \rightarrow \gamma$ (3b) transformations are presented for the

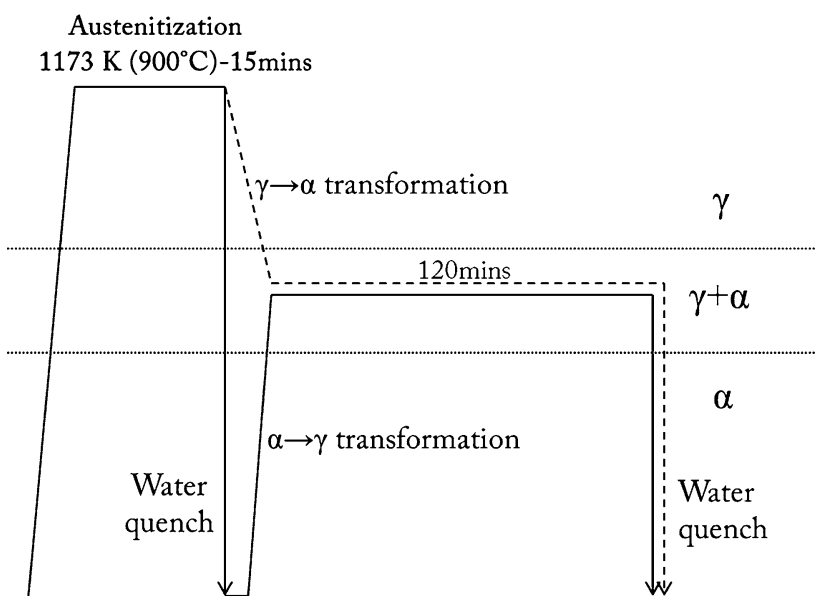

Fig. 2-Heat treatment diagram illustrating two different transformation routes. four alloys studied. The LE model predicts that the kinetics depends on the initial microstructure, while the FE predictions for each of the alloys studied are transformation path independent. The LE model predicts that no transformation, i.e., $f_{\alpha} \approx 0$ occurs in case of an austenitic starting state. Interestingly, however, for all alloys the LE model predicts that the $\alpha^{\prime} \rightarrow \gamma$ transformation progresses significantly. As can be seen in Figure 3(b), there is a primary fast mode in the kinetics of $\alpha^{\prime} \rightarrow \gamma$ transformation during the first 10 seconds followed by a rather sluggish increase in $\gamma$ fraction (NPLE/PLE transition). This interesting phenomenon implies that the NPLE/PLE transition point strongly depends on the transformation path and the alloy composition, as was also observed for the lower Mn levels. ${ }^{[16]}$ According to LE model, when the concentration of $\mathrm{Mn}$ in ferrite is the same as in the austenite and the transformation is controlled by $\mathrm{C}$ diffusion in initial phase only and the process is fast. Since the diffusivity of $\mathrm{C}$ in ferrite is much higher than that in austenite, the $\alpha^{\prime} \rightarrow \gamma$ transformation rate is significantly faster than the $\gamma \rightarrow \alpha$ phase transformation. Furthermore, differences in the NPLE/PLE transition of four alloys reveals effects of $\mathrm{Mn}$ and $\mathrm{Si}$ in the $\alpha^{\prime} \rightarrow \gamma$ transformation, as shown in Figure 3(b). An increase in the Mn content, results in an earlier NPLE/PLE transition and a higher final austenite fraction for a fixed intercritical annealing temperature. In addition, the presence of concentration spike of substitutional alloying elements at the interface in composition profiles in low transformation rate confirms the transition in kinetics of the phase transformation. ${ }^{[15,27,31,48]} \mathrm{A}$ comparison of the red and blue transformation curves shows that changes in the Si level only have a small effect on the transformation behavior.

As stated earlier, real metallurgical isothermal transformation experiments were performed in order to validate the LE model predictions. In Figure 4, the typical microstructures of the sample A $(0.1$ wt pet $\mathrm{C} \&$ 3.0 wt pet Mn) quenched from the $\gamma \rightarrow \alpha$ and $\alpha^{\prime} \rightarrow \gamma$

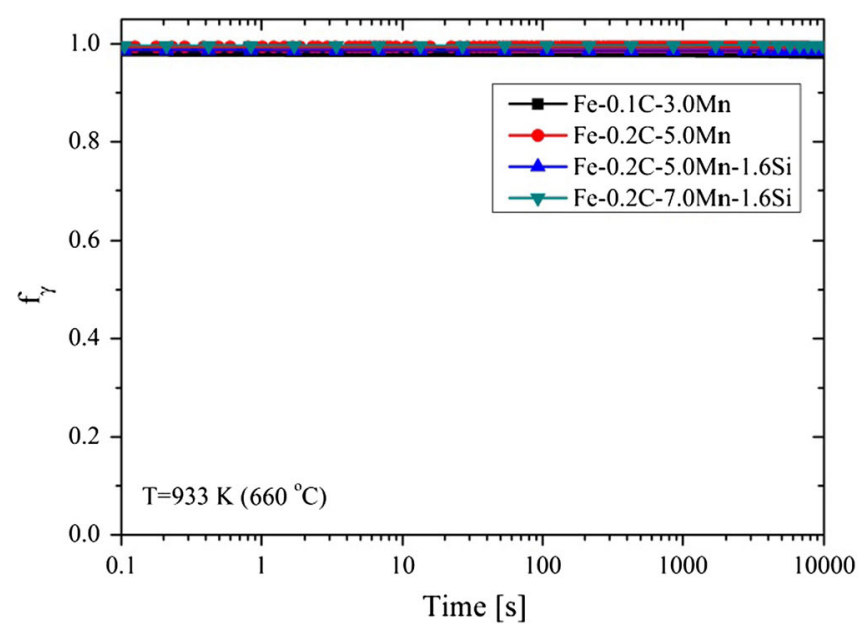

(a)

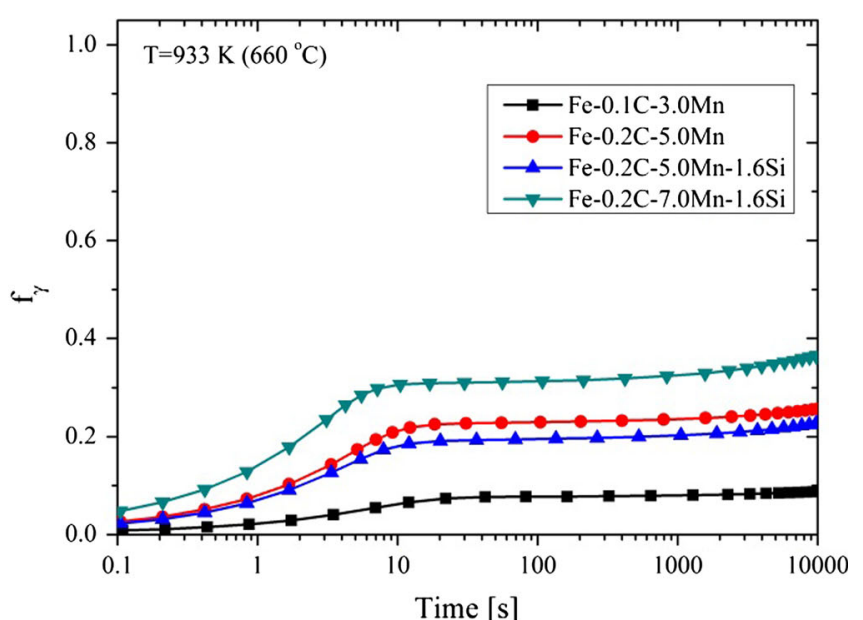

(b)

Fig. 3-Austenite fraction as a function of heating time in the intercritical zone predicted by LE modeling for $(a)$ austenite-to-ferrite and (b) martensite-to-austenite transformation at $T=933 \mathrm{~K}\left(660^{\circ} \mathrm{C}\right)$. 


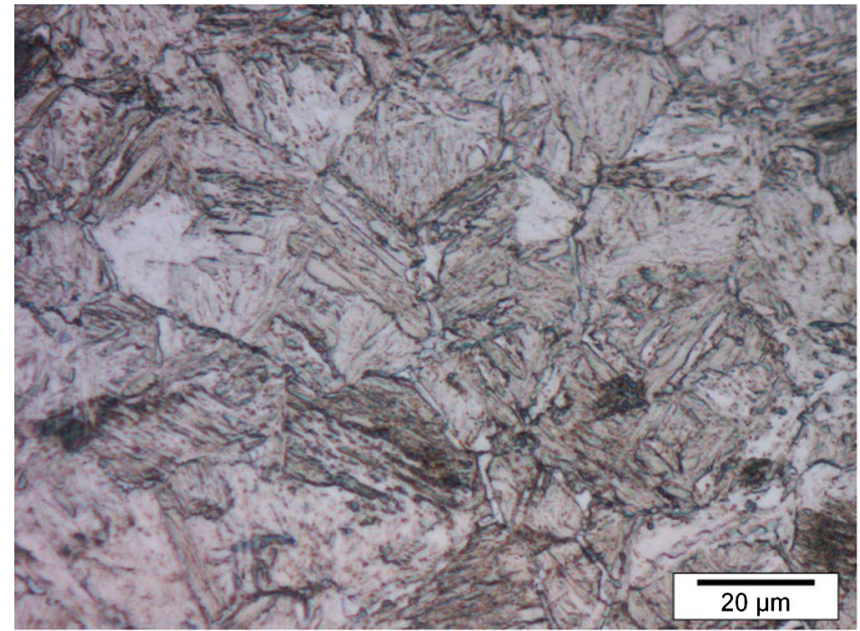

(a)

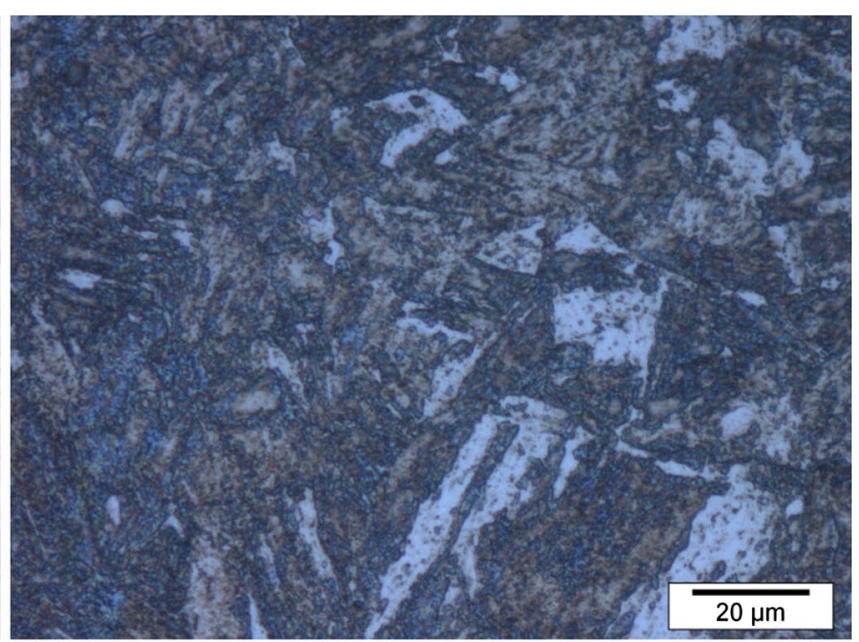

(b)

Fig. 4-The typical microstructures of the Fe-0.1C-3.0Mn alloy sample quenched after $(a)$ the austenite-to-ferrite transformation and (b) martensite-to-austenite transformation at $T=933 \mathrm{~K}\left(660{ }^{\circ} \mathrm{C}\right)$. The annealing time is $7200 \mathrm{~s}$.

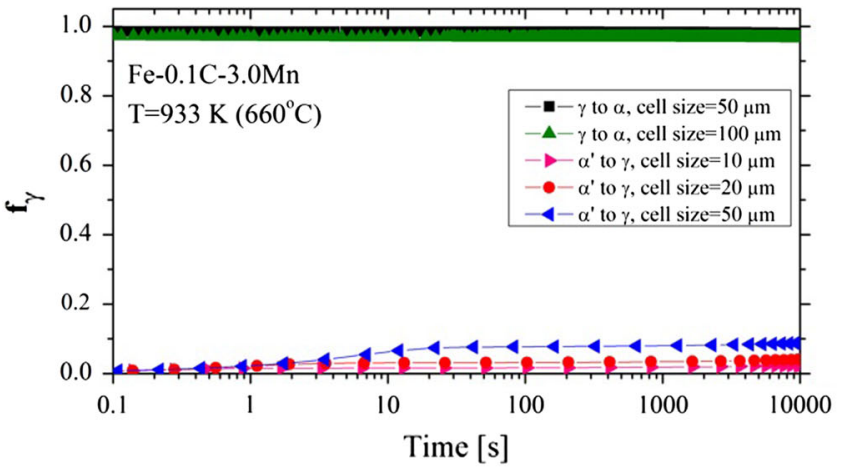

(a)

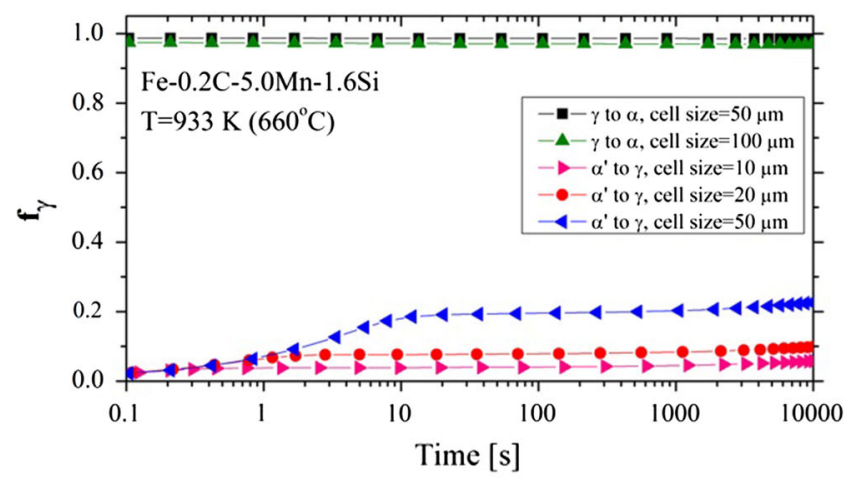

(c)

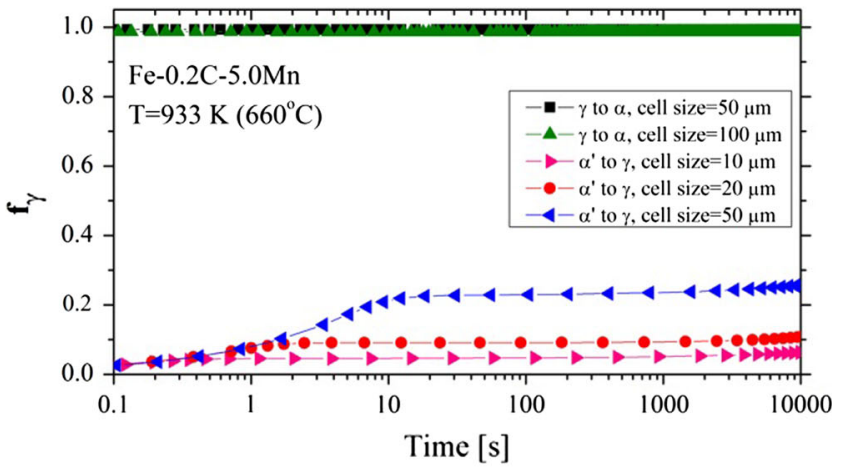

(b)

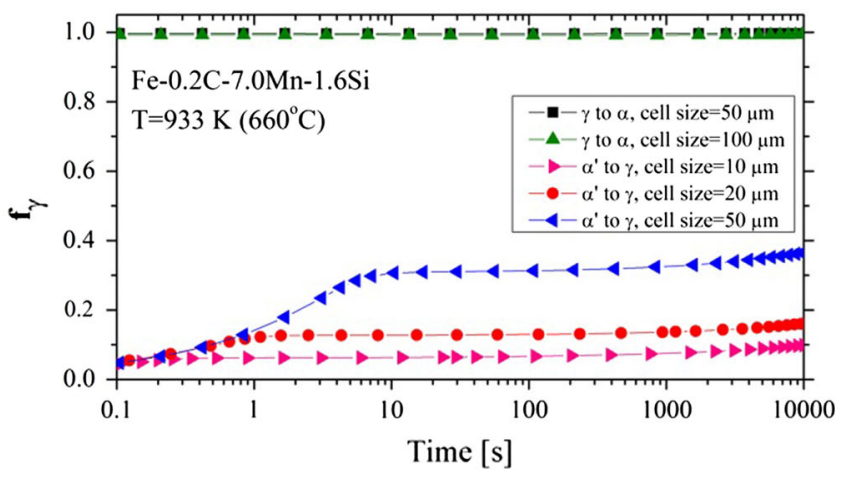

(d)

Fig. 5-The effect of cell size on the simulated kinetics of phase transformations in (a) Fe-0.1C-3.0Mn, (b) Fe-0.2C-5.0Mn, (c) Fe-0.2C-5.0Mn$1.6 \mathrm{Si}$ and $(d) \mathrm{Fe}-0.2 \mathrm{C}-7.0 \mathrm{Mn}-1.6 \mathrm{Si}$.

phase transformations, after annealing for 7200 seconds at $T=933 \mathrm{~K}\left(660{ }^{\circ} \mathrm{C}\right)$, are presented. The micrographs show that only a very small fraction of austenite transformed into grain boundary ferrite during the $\gamma \rightarrow \alpha$ transformation. In the experiments, the average prior austenite grain size was found to be $\sim 50 \mu \mathrm{m}$. As mentioned above, simulations were done assuming a variety of cell sizes from 10 to $100 \mu \mathrm{m}$. Figures 5(a) through (d) illustrates the effect of cell size on the transformations kinetics in different alloys at $T=933 \mathrm{~K}\left(660{ }^{\circ} \mathrm{C}\right)$ for both $\gamma \rightarrow \alpha$ and the $\alpha^{\prime} \rightarrow \gamma$ transformations. Changing the simulation cell size from 50 to $100 \mu \mathrm{m}$ does not have a noticeable impact on the kinetics of $\gamma \rightarrow \alpha$ transformation. However, for all 


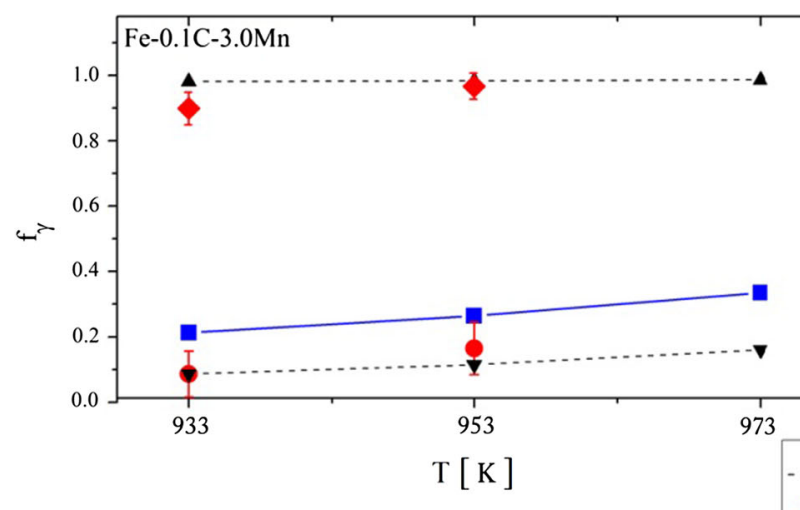

(a)

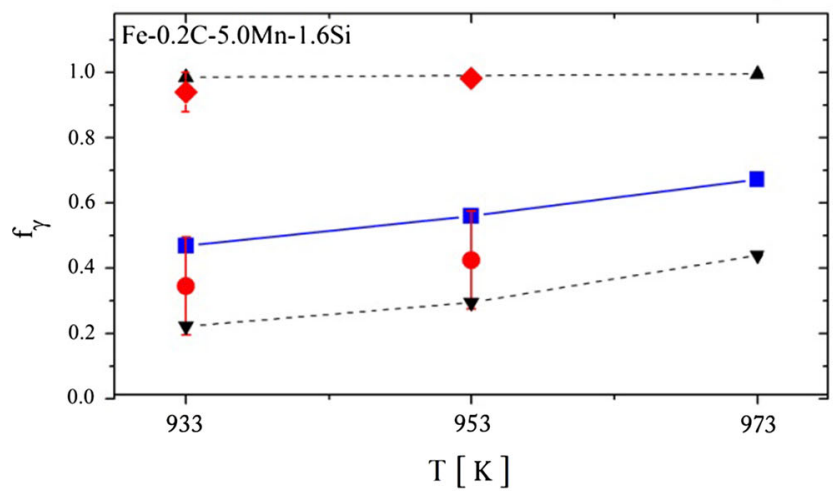

(c)

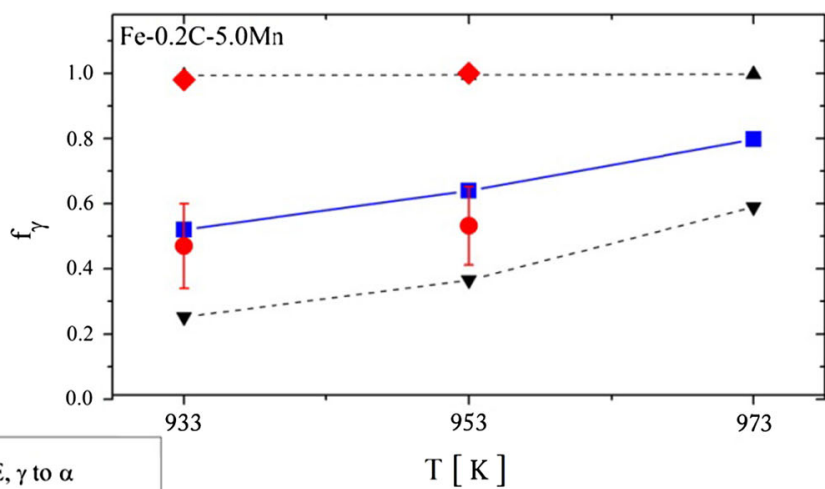

(b)

Experiment, $\alpha$ to $\gamma$ LE, $\alpha$ to $\gamma$

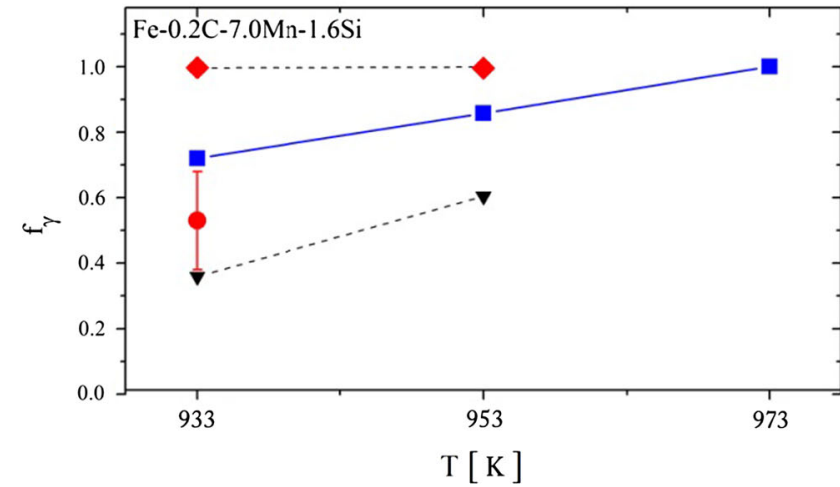

(d)

Fig. 6-Experimental and modeling results of austenite fraction in $(a) \mathrm{Fe}-0.1 \mathrm{C}-3.0 \mathrm{Mn},(b) \mathrm{Fe}-0.2 \mathrm{C}-5.0 \mathrm{Mn},(c) \mathrm{Fe}-0.2 \mathrm{C}-5.0 \mathrm{Mn}-1.6 \mathrm{Si}$, and $(d)$ Fe$0.2 \mathrm{C}-7.0 \mathrm{Mn}-1.6 \mathrm{Si}$.

alloys the kinetics in the $\alpha^{\prime} \rightarrow \gamma$ transformation is significantly affected when reducing the simulation cell size from 50 to $10 \mu \mathrm{m}$, as the kinetic transition from fast carbon controlled to slow alloying element-controlled growth (NPLE/PLE transition) depends on cell size. Thus, the value of $f_{\gamma}$ at the end of simulation time, approximately halves by halving the cell size. To highlight only the effect of composition and initial microstructure on the transformation, the cell size in the $\alpha^{\prime} \rightarrow \gamma$ simulation is taken the same as for the $\gamma \rightarrow \alpha$ transformation, i.e., $50 \mu \mathrm{m}$. The effect of simulation cell size will be re-addressed when comparing the experimental results to the model predictions.

Figure 6 shows the fractions of austenite as predicted by the LE model, the FE model and the experimental results for both $\gamma \rightarrow \alpha$ and the $\alpha^{\prime} \rightarrow \gamma$ transformations for all studied alloys at $T=933 \mathrm{~K}, 953 \mathrm{~K}$, and $973 \mathrm{~K}$ $\left(660^{\circ} \mathrm{C}, 680{ }^{\circ} \mathrm{C}\right.$, and $\left.700{ }^{\circ} \mathrm{C}\right)$. The experimental values at $973 \mathrm{~K}\left(700^{\circ} \mathrm{C}\right)$ are not plotted in this figure because of the high uncertainty in the quantification of the phase fractions due to the fine mixture of two phases and the lower optical contrast difference. As seen in Figure 6(a), the LE model predictions in Fe-0.1C$3.0 \mathrm{Mn}$ system are in good agreement with experimental values. The FE model predicted austenite fraction is not reached at any of the temperatures studied, irrespective of the starting microstructure. For Mn concentrations beyond 3 wt pct, the data in Figures 6(b) through (d), show that the final austenite fractions in the $\gamma \rightarrow \alpha$ transformation are well predicted by the LE model. However, the differences between simulations and experiments for $\alpha^{\prime} \rightarrow \gamma$ transformation become larger at higher Mn and Si levels. The LE model underestimates the experimental austenite fractions. This observation is in agreement with Enomoto's earlier results. ${ }^{[4]}$ Comparison of Figures 6(b) and (c) confirms the systematic effect of $\mathrm{Si}$ on reducing austenite formation. It is worth noting that according to Figure 6, the experimental values of $f_{\gamma}$ in $\alpha^{\prime} \rightarrow \gamma$ phase transformation get closer to the full equilibrium predictions upon increasing $\mathrm{Mn}$ content. This phenomenon can be attributed to the availability of large number of nucleation sites in the initial martensitic microstructure and the late occurrence of the NPLE/PLE transition.

\section{DISCUSSION}

We first focus on the results obtained at a fixed temperature of $T=933 \mathrm{~K}\left(660^{\circ} \mathrm{C}\right)$. The isothermal sections of the Fe-C-Mn phase diagram, without and with $1.6 \mathrm{wt}$ pct $\mathrm{Si}$, created by Thermo-Calc coupled to the TCFe7 database are shown in Figure 7. According to References 46 and 50 in the case of ferrite formation 
(a) Isothermal holding (Ferrite formation)

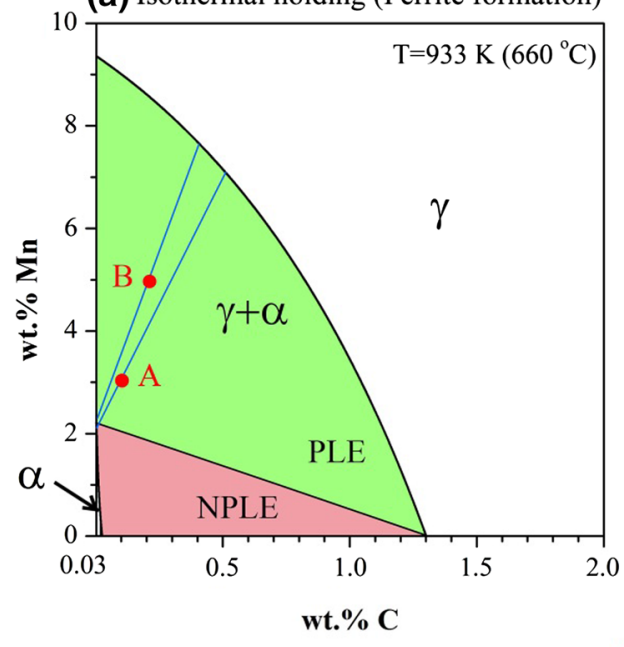

(c) Isothermal holding (Ferrite formation)

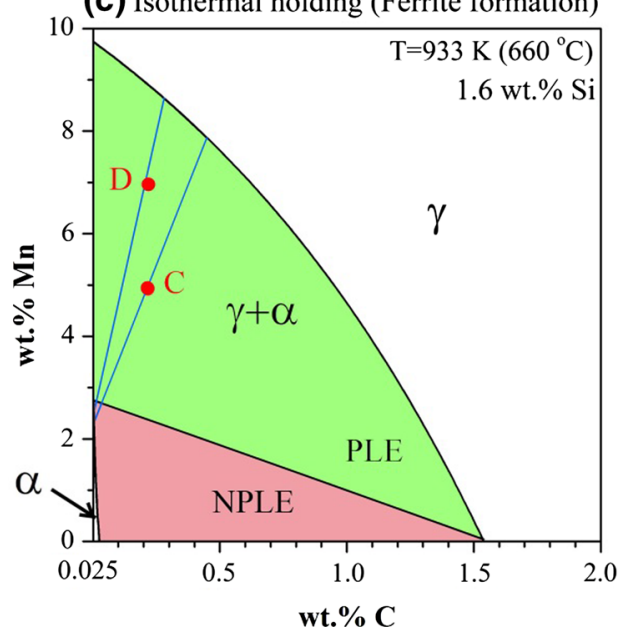

(b) Intercritical anealing (Austenite formation)

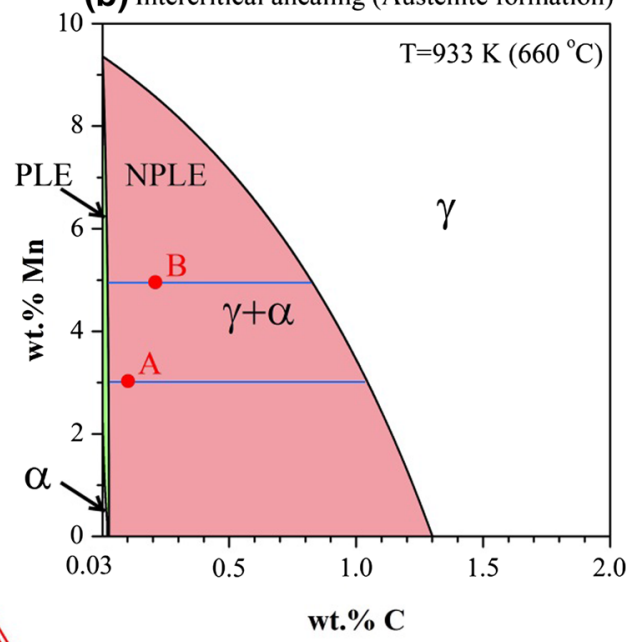

(d) Intercritical anealing (Austenite formation)

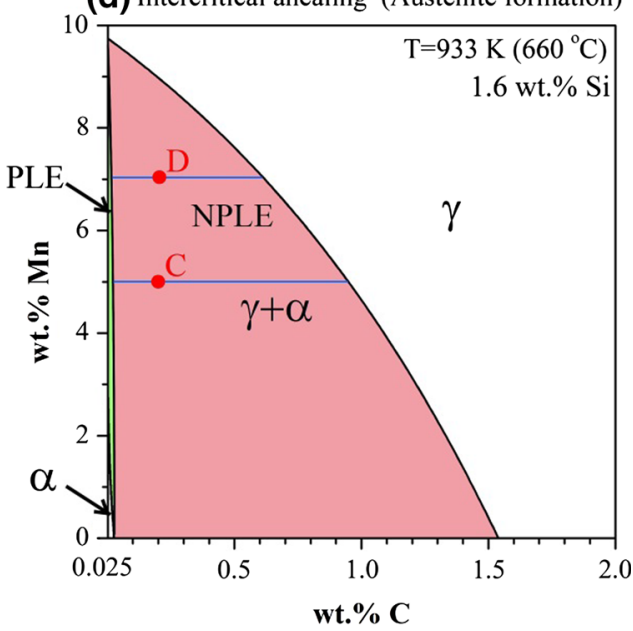

Fig. 7-Isothermal section of an equilibrium phase diagram showing boundary of PLE/NPLE at $T=933 \mathrm{~K}\left(660^{\circ} \mathrm{C}\right)$ in $(a)$ ferrite and $(b)$ austenite formations in C-Mn steel, and $(c)$ ferrite and $(d)$ austenite formations in C-Mn steel with 1.6 wt pct Si.

(Figures 7(a) and (c), the boundaries between PLE region (shown in green color) and NPLE region (shown in pink color) run between the intersection of the $\alpha /(\alpha+\gamma)$ phase boundary with the axis of the Mn content and the intersection of the $\gamma /(\alpha+\gamma)$ phase boundary with the axis of the $\mathrm{C}$ content. For the austenite formation (Figures 7(b) and (d)), the PLE/ NPLE boundary can be described by the curve connecting the intersection of the $\gamma /(\alpha+\gamma)$ phase boundary with the axis of the Mn content to the intersection of $\alpha /(\alpha+\gamma)$ phase boundary with the axis of the $\mathrm{C}$ content. The points indicated by $\mathrm{A}, \mathrm{B}, \mathrm{C}$, and $\mathrm{D}$ in Figures 7(a) through (d) refer to the alloys specified in Table I. For all four alloys, ferrite growth from austenite starts in the PLE mode. Hence both $\mathrm{C}$ and $\mathrm{Mn}$ (and $\mathrm{Si}$ in the case of $\mathrm{Fe}-0.2 \mathrm{C}-5.0 \mathrm{Mn}-1.6 \mathrm{Si}$ and $\mathrm{Fe}-0.2 \mathrm{C}-7.0 \mathrm{Mn}-1.6 \mathrm{Si}$ alloys) redistribute into the untransformed austenite according to the PLE isoactivity (so-called tie-lines) indicated by blue lines in Figures 7(a) and (c). The tie-lines in PLE mode region are obtained when the chemical potentials of each component are equal in both $\gamma$ and $\alpha$ phases. Since both substitutional alloying elements have significantly lower diffusion coefficients than $\mathrm{C}$, the ferrite growth rate is sluggish and is controlled by partioning of $\mathrm{Mn}$ (and $\mathrm{Si}) .^{[51]}$ As shown in Figures 7(b) and (d), the austenite formation from ferrite for the four alloys starts under NPLE mode and continues with C depletion in the untransformed ferrite according to the horizontal blue tie-lines. Carbon is redistributed to keep the chemical potentials equal in each phase and $\mathrm{Mn}$ has the same concentration both in $\gamma$ and $\alpha$ and has unequal chemical potentials in both phases. When the composition of ferrite reaches the NPLE/PLE boundary, the austenite growth mode switches to the PLE mode. Albeit the $\alpha^{\prime} \rightarrow \gamma$ transformation starts in NPLE mode, $\mathrm{Mn}$ and $\mathrm{Si}$ concentration profiles also develop across the interface at prolonged isothermal holding time.$^{[46,52]}$ The transformation stops well before the full equilibrium condition is reached. These observations are in good agreement with the Dictra simulations shown in Figures 3(a) and (b). 


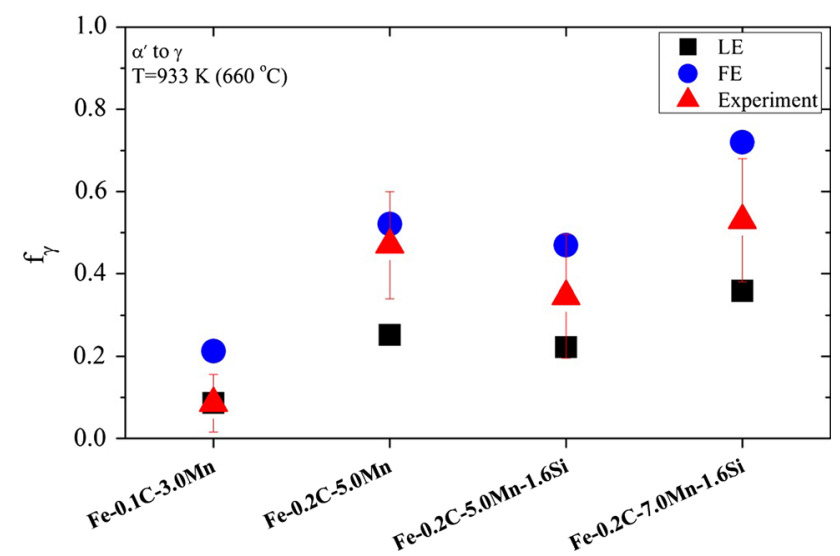

Fig. 8-Heat treatment diagram illustrating martensite-to-austenite phase transformation at $T=933 \mathrm{~K}\left(660^{\circ} \mathrm{C}\right)$.

Figure 8 summarizes the model and experimental results for the four alloys studied. It is clear that that $\mathrm{Mn}$ and $\mathrm{Si}$ content directly affect the $\mathrm{Ae}_{1}$ and $\mathrm{Ae}_{3}$ temperatures, and thus the full equilibrium fractions of ferrite or austenite at the fixed temperature of $933 \mathrm{k}\left(660^{\circ} \mathrm{C}\right)$. As reported in References 53 through 55 nucleation of austenite not only occurs at the grain boundaries but also at interfaces of $\alpha / \alpha$ and $\alpha /$ carbides. This simultaneous nucleation on the carbides is not taken into account in the 1D model. It is worth noting that formation of cementite, which is neglected in the modeling part, affects the experimental value of $f_{\gamma}$. Although $\mathrm{Si}$ is known to retard the cementite formation, however, it does not completely suppress the precipitation and cementite will appear after a long annealing times. ${ }^{[56,57]}$

It is worth noting that considering the observed effect of simulation cell size on the predicted value of $f$, it is clear that varying the cell size does not affect the overall trend of predicted fractions for both $\gamma \rightarrow \alpha$ and the $\alpha^{\prime} \rightarrow \gamma$ transformations. In the current analysis, the cell length of $\alpha^{\prime} \rightarrow \gamma$ is taken the same as the $\gamma \rightarrow \alpha$ transformation, i.e., $50 \mu \mathrm{m}$. Using the lath width for the $\alpha^{\prime} \rightarrow \gamma$ transformation might be an alternative, however, due to the continuous recovery of martensite and low angle lath boundaries at such high temperature, capturing the effect of a transient initial effective computational cell size is complex and outside the scope of the present study.

\section{CONCLUSIONS}

In this study, the effect of initial microstructure and isothermal holding temperature in the intercritical zone was studied experimentally and theoretically for a series of steels with Mn content up to $7 \mathrm{wt}$ pct. The following results are obtained:

(1) There is a significant difference in the transformation rate between the $\gamma \rightarrow \alpha$ and $\alpha^{\prime} \rightarrow \gamma$ transformations.

(2) For the alloy compositions and temperatures considered here, the $\gamma \rightarrow \alpha$ transformation starts in PLE mode and the ferrite growth rate is constrained by the redistribution of $\mathrm{Mn}$ and $\mathrm{Si}$. However in the case of the $\alpha^{\prime} \rightarrow \gamma$ transformation, the austenite growth starts in the NPLE mode and shifts to PLE by depletion of $\mathrm{C}$ in the martensitic ferrite matrix.

(3) For Mn levels between 3 and $7 \mathrm{wt}$ pct, the LE model is qualitatively correct but does not predict the austenite fraction in $\alpha^{\prime} \rightarrow \gamma$ transformation with high enough accuracy.

(4) For the higher Mn level steels, the additional intragranular nucleation of austenite during $\alpha^{\prime} \rightarrow \gamma$ transformation increases the $f_{\gamma}$ at the end of the intercritical holding stage of $10^{4}$ seconds, which is not captured by $1 \mathrm{D}$ geometry of LE model.

\section{ACKNOWLEDGMENTS}

The authors acknowledge ArcelorMittal, France for financial support.

\section{OPEN ACCESS}

This article is distributed under the terms of the Creative Commons Attribution 4.0 International License (http://creativecommons.org/licenses/by/4.0/), which permits unrestricted use, distribution, and reproduction in any medium, provided you give appropriate credit to the original author(s) and the source, provide a link to the Creative Commons license, and indicate if changes were made.

\section{REFERENCES}

1. R. Ding, D. Tang, and A. Zhao: Scripta Mater., 2014, vol. 88, pp. 21-24.

2. E. Gamsjäger, J. Svoboda, and F.D. Fischer: Comput. Mater. Sci., 2005, vol. 32 (3-4), pp. 360-69.

3. A.T.W. Kempen, F. Sommer, and E.J. Mittemeijer: Acta Mater., 2002, vol. 50 (14), pp. 3545-55.

4. J.J. Wits, T.A. Kop, Y. van Leeuwen, J. Seitsma, and S. van Der Zwaag: Mater. Sci. Eng. A, 2000, vol. 283 (1-2), pp. 234-41.

5. G.P. Krielaart, J. Sietsma, and S. van der Zwaag: Mater. Sci. Eng. A, 1997, vol. 237 (2), pp. 216-23.

6. C.-S. Oh, H. Han, C. Lee, T.-H. Lee, and S.-J. Kim: Met. Mater. Int., 2004, vol. 10 (5), pp. 399-406.

7. S. Lee and B. De Cooman: Metall. Mater. Trans. A, 2013, vol. 44A, pp. 5018-24.

8. E. Emadoddin, A. Akbarzadeh, and G. Daneshi: Mater. Charact., 2006, vol. 57 (4-5), pp. 408-13.

9. G.N. Haidemenopoulos, N. Aravas, and I. Bellas: Mater. Sci. Eng. A, 2014, vol. 615, pp. 416-23.

10. A.I. Katsamas, A.M. Vasilakos, and G.N. Haidemenopoulos: Steel Res., 2000, vol. 71 (9), pp. 351-56.

11. H.S. Zurob, C.R. Hutchinson, A. Béché, G.R. Purdy, and Y.J.M. Bréchet: Acta Mater., 2008, vol. 56 (10), pp. 2203-11.

12. H.S. Zurob, C.R. Hutchinson, Y. Bréchet, H. Seyedrezai, and G.R. Purdy: Acta Mater., 2009, vol. 57 (9), pp. 2781-92.

13. H. Chen and S. van der Zwaag: Acta Mater., 2013, vol. 61 (4), pp. $1338-49$.

14. H. Chen and S. van der Zwaag: Acta Mater., 2014, vol. 72, pp. $1-12$. 
15. H. Chen and S. van der Zwaag: Metall. Mater. Trans. A, 2014, vol. $45 \mathrm{~A}$, pp. $3429-37$.

16. H. Chen, X. Xu, W. Xu, and S. van der Zwaag: Metall. Mater. Trans. A, 2014, vol. 45A, pp. 1675-79.

17. C.R. Hutchinson, A. Fuchsmann, H.S. Zurob, and Y. Brechet: Scripta Mater., 2004, vol. 50 (2), pp. 285-90.

18. M. Hillert and J. Ågren: Scripta Mater., 2004, vol. 50 (5), pp. 697-99.

19. M. Hillert: Internal Report, Swedish Institute of Metals Research, Stockholm, 1953

20. A. Hultgren: Trans. Am. Soc. Met., 1947, vol. 39, pp. 915-1005.

21. D.E. Coates: Metall. Trans., 1972, vol. 3 (5), pp. 1203-12.

22. J.S. Kirkaldy: Can. J. Phys., 1958, vol. 36 (7), pp. 907-16.

23. M. Hillert: Scripta Mater., 2002, vol. 46 (6), pp. 447-53.

24. M. Hillert and J. Ågren: Scripta Mater., 2002, vol. 46 (6), pp. $455-57$.

25. M. Hillert and M. Rettenmayr: Acta Mater., 2003, vol. 51 (10), pp. 2803-09.

26. E. Gamsjäger, H. Chen, and S. van der Zwaag: Comput. Mater. Sci., 2014, vol. 83, pp. 92-100.

27. H. Chen, K. Zhu, L. Zhao, and S. van der Zwaag: Acta Mater., 2013, vol. 61 (14), pp. 5458-68

28. C. Capdevila, J. Cornide, K. Tanaka, K. Nakanishi, and E. UronesGarrote: Metall. Mater. Trans. A, 2011, vol. 42A, pp. 3719-28.

29. G. Sheng and Z.G. Yang: Mater. Lett., 2008, vol. 62 (12-13), pp. 1933-36.

30. H.S. Zurob, D. Panahi, C.R. Hutchinson, Y. Brechet, and G.R. Purdy: Metall. Mater. Trans. A, 2013, vol. 44A, pp. 3456-71.

31. H. Chen, B. Appolaire, and S. van der Zwaag: Acta Mater., 2011, vol. 59 (17), pp. 6751-60.

32. H. Chen, W. Xu, M. Goune, and S. van der Zwaag: Philos. Mag. Lett., 2012, vol. 92 (10), pp. 547-55.

33. H. Luo, J. Shi, C. Wang, W. Cao, X. Sun, and H. Dong: Acta Mater., 2011, vol. 59 (10), pp. 4002-14.

34. J. Agren: Acta Metall., 1982, vol. 30 (4), pp. 841-51.

35. R. Wei, M. Enomoto, R. Radian, H.S. Zurob, and G.R. Purdy: Acta Mater., 2013, vol. 61 (2), pp. 697-707.

36. E. Hersent, K. Marthinsen, and E. Nes: Metall. Mater. Trans. A, 2014, vol. 45A, pp. 4882-90.

37. C. Wang, W. Cao, J. Shi, C. Huang, and H. Dong: Mater. Sci. Eng. A, 2013, vol. 562, pp. 89-95.
38. R. Zhang, W.Q. Cao, Z.J. Peng, J. Shi, H. Dong, and C.X. Huang: Mater. Sci. Eng. A, 2013, vol. 583, pp. 84-88.

39. A. Arlazarov, M. Gouné, O. Bouaziz, A. Hazotte, G. Petitgand, and P. Barges: Mater. Sci. Eng. A, 2012, vol. 542, pp. 31-39.

40. J. Lee, S. Sohn, S. Hong, B.-C. Suh, S.-K. Kim, B.-J. Lee, N. Kim, and S. Lee: Metall. Mater. Trans. A, 2014, vol. 45A, pp. 5419-30.

41. S.S. Sohn, S. Lee, B.J. Lee, and J.H. Kwak: JOM, 2014, vol. 66 (9), pp. 1857-67.

42. J. Han, S.-J. Lee, J.-G. Jung, and Y.-K. Lee: Acta Mater., 2014, vol. 78, pp. 369-77.

43. I. Gutierrez-Urrutia and D. Raabe: Scripta Mater., 2013, vol. 68 (6), pp. 343-47.

44. H. Guo, G.R. Purdy, M. Enomoto, and H.I. Aaronson: Metall. Mater. Trans. A, 2006, vol. 37A, pp. 1721-29.

45. H. Guo and M. Enomoto: Metall. Mater. Trans. A, 2007, vol. 38A, pp. 1152-61.

46. N. Nakada, K. Mizutani, T. Tsuchiyama, and S. Takaki: Acta Mater., 2014, vol. 65, pp. 251-58.

47. H. Chen and S. van der Zwaag: Philos. Mag. Lett., 2011, vol. 92 (2), pp. 86-92.

48. H. Chen, R. Kuziak, and S. van der Zwaag: Metall. Mater. Trans. A, 2013, vol. 44A, pp. 5617-21.

49. M. Enomoto: Trans. Iron Steel Inst. Jpn., 1988, vol. 28 (10), pp. 826-35.

50. C. Atkinson, T. Akbay, and R.C. Reed: Acta Metall. Mater., 1995, vol. 43 (5), pp. 2013-31.

51. Z.Q. Liu, G. Miyamoto, Z.G. Yang, and T. Furuhara: Acta Mater., 2013, vol. 61 (8), pp. 3120-29.

52. G.-H. Zhang, Y.-U. Heo, E.-J. Song, and D.-W. Suh: Met. Mater. Int., 2013, vol. 19 (2), pp. 153-58.

53. J. Huang, W.J. Poole, and M. Militzer: Metall. Mater. Trans. A, 2004, vol. 35 A, pp. 3363-75.

54. C.I. Garcia and A.J. Deardo: Metall. Trans. A, 1981, vol. 12A, pp. $521-30$.

55. J. Lis and A. Lis: J. Achiev. Mater. Manuf. Eng., 2008, vol. 26 (2), p. 195.

56. E. Kozeschnik and H.K.D.H. Bhadeshia: Mater. Sci. Technol., 2008, vol. 24 (3), pp. 343-47.

57. B. Kim, C. Celada, D. San Martín, T. Sourmail, and P.E.J. Rivera-Díaz-del-Castillo: Acta Mater., 2013, vol. 61 (18), pp. 6983-92. 